\title{
KAJIAN DAMPAK PENURUNAN DAUR TANAMAN Acacia crassicarpa A. Cunn TERHADAP NILAI PRODUKSI DAN SOSIAL
}

\author{
(Study of Reduction Cycle Impact of Acacia crassicarpa A. Cunn \\ Plantation to Production Value and Social Aspect) \\ Suhartati ${ }^{1)}$, Yeni Aprianis ${ }^{2)}$, Avri Pribadi ${ }^{2)}$ dan/and Yanto Rochmayanto ${ }^{3)}$ \\ "Balai Penelitian Kehutanan Makassar \\ Jl. Perintis Kemerdekaan Km 16.5 Makassar 90243 \\ Telp. 0411-554049; Fax. 0411-554058 \\ ${ }^{2)}$ Balai Penelitian Teknologi Serat Tanaman Hutan \\ Jl. Raya Bangkinang-Kuok Km 9, Bangkinang Kampar, Riau 28294 \\ Telp. 0762-7000121; Fax. 0762-7000122 \\ ${ }^{3}$ Pusat Penelitian dan Pengembangan Perubahan Iklim dan Kebijakan \\ Kampus Balitbang Kehutanan Jl. Gunung Batu No. 5, Kotak Pos 272 Bogor \\ Telp. 0251-8633944; Fax. 0251-8634924
}

Naskah masuk : 22 Mei 2012; Naskah diterima : 1 April 2013

\begin{abstract}
Acacia crassicarpa A. Cunn is one among the Acacia species that developed in industrial timber plantations and used as raw material for pulp and paper industries. Generally this plantation has two main problems, which are low productivity and long time rotation. The problems have made industrial timber plantations reduced the rotation from six years to four and five years to fulfill the requirement for wood intake. The research aims at evaluating the effect of reduction A. crassicarpa rotation on productivity, wood properties, and financial aspect. This research used sample plots of 0,1 ha for each stand age to observe the aspects of production and properties of wood, and used labor demand approach to observe social and financial aspects. The result showed that the highest productivity rates of A. crassicarpa occurred at the fourth and fifth years. The wood properties aspect show that the pulp quality of A. crassicarpa at the age of 4-6 years is classified into the first and second quality class. The social and financial aspects, especially the labor showed that the highest rate demand occurred in the fourth. The result also showed that the reduction of crassicarpa rotation does not have negative effect on the principles of sustainable forest management.
\end{abstract}

Keywords: Acacia crassicarpa, decrease of plantation rotation, sustainable forest management

\begin{abstract}
ABSTRAK
A. crassicarpa A. Cunn adalah salah satu jenis tanaman pokok yang dikembangkan pada Hutan Tanaman Industri Pulp (HTI) sebagai bahan baku pulp dan kertas. Permasalahan pada jenis tanaman ini, produktivitasnya masih rendah serta daurnya masih panjang. Untuk kesinambungan suplai kayu, maka perusahaan HTI menurunkan daur tanaman dari umur 6 tahun menjadi umur 4-5 tahun agar bahan baku kayu tetap tersedia sesuai kebutuhan Industri. Penelitian ini bertujuan untuk mengkaji dampak penurunan daur $A$. crassicarpa terhadap nilai produksi dan sifat kayunya, kondisi ekologis serta aspek sosial. Metode penelitian dilakukan dengan membuat plot sampling pada areal HTI untuk mengamati aspek produksi dan sifat kayunya yang meliputi parameter volume pohon, sifat kayu dan nilai financial sedangkan aspek sosial difokuskan pada serapan tenaga kerja terhadap pengelolaan HTI. Hasil kajian menunjukkan bahwa produksi tertinggi pada umur antara $4-5$ tahun, diindikasikan dengan tercapainya daur teknis dan ekonomis pada umur tersebut. Sedangkan sifat kimia dan dimensi serat kayunya tergolong kualitas I dan II dari umur 4-6 tahun, dengan rendamen tertinggi pada kayu umur 4 tahun. Aspek sosial khususnya penyerapan tenaga kerja menunjukkan nilai terbesar pada daur umur 4 tahun. Berdasakan hasil kajian ini diperoleh bahwa penurunan daur HTI A. crassicarpa tidak berdampak negatif terhadap pengelolaan hutan lestari.
\end{abstract}

Kata kunci : Hutan tanaman, Acacia crassicarpa, lahan gambut, daur 


\section{PENDAHULUAN}

Pembangunan Hutan Tanaman Industri untuk pulp (HTI-Pulp) khususnya di Sumatera mengembangkan Acacia mangium Willd, Eucalyptus dan Acacia crassicarpa A. Cunn. Jenis ini dikembangkan sebagai tanaman pokok karena memenuhi persyaratan sebagai bahan baku kayu untuk industri dan kertas, serta telah dikuasainya teknik silvikulturnya.

Pulau Sumatera sebagian wilayahnya terdiri atas lahan gambut, sehingga konsesi pengembangan HTI diarahkan ke lahan gambut. A. crassicarpa dapat beradaptasi pada lahan gambut, sehingga terpilih sebagai tanaman pokok untuk lahan gambut (wet land). Permasalahannya adalah produktivitasnya masih rendah karena persen hidupnya (survival) rendah serta daurnya masih panjang. PT. Arara Abadi (2008), melaporkan tanaman A. crassicarpa umur 3 tahun persen hidupnya sebesar $49,82 \%$, sedangkan pada umur 4 tahun hanya mencapai $27,38 \%$. Secara umum kebutuhan bahan baku kayu saat ini, belum memenuhi target kapasitas industri dan kertas. Untuk kesinambungan ketersediaan bahan baku kayu tersebut, perusahaan HTI menurunkan daur tebang dari umur 6 tahun menjadi umur 4-5 tahun pada A. crassicarpa. Seiring dengan ditemukannya klon-klon unggul disertai penerapan silvikultur intensif (silin), maka secara operasional HTI A. crassicarpa dipanen antara umur 4-5 tahun untuk tujuan bahan baku pulp dan kertas.

Azaz pengeloaan hutan lestari (sustainable forest management), adalah prinsip pengelolaan hutan dengan tetap mempertimbangkan faktor kelestarian produksi, ekologis dan sosial. Oleh karena itu, kebijakan penurunan daur pada HTI $A$. crassicarpa atas pertimbangan faktor-faktor tersebut. Berdasarkan hal ini, dilakukan kajian yang bertujuan untuk mengetahui dampak penurunan daur HTI jenis A.carssicarpa terhadap kelestarian produksi, ekologis dan sosial. Hasil kajian ini dapat menjadi bahan referensi bagi pihak pemerintah untuk mengeluarkan Kebijakan Penurunan Daur HTI A.carssicarpa. Penetapan kebijakan ini menjadi pedoman bagi perusahaan untuk menetapkan standar operasional pelaksanaan (SOP) terhadap pengelolaan HTI pulp, khususnya untuk wilayah Sumatera.

\section{METODE PENELITIAN}

\section{A. Lokasi Penelitian}

Penelitian dilaksanakan pada tegakan A. crassi- carpa di lahan gambut di areal HTI PT. Arara Abadi di Riau, HTI PT. RAPP di Riau, dan HTI PT. Wira Karya Sakti di Jambi.

\section{B. Bahan Penelitian}

Bahan yang digunakan adalah areal tegakan A.crassicarpa berbagai kelas umur (umur $3 ; 4 ; 5$ dan 6 tahun, perlengkapan lapangan dan sarana laboratorium, zat kimia, alat pengujian contoh tanah dan kayu, tally sheet, daftar kuisioner dan lain-lain.

\section{Analisis Data}

1. Aspek produksi dan sifat kayunya

a. Faktor pertumbuhan

Parameter yang diamati meliputi: pertumbuhan tegakan, volume tegakan, riap volume, rendamen, kualitas dan aspek finansial. Data pendukung yaitu: kondisi fisik lapangan meliputi posisi geografis, jenis tanah, ketinggian tempat, topografi, kelerengan, iklim, jenis tanah, dan analisia sifat tanah di lokasi plot sampling.

Untuk menghitung riap pertumbuhan dilakukan dengan metode Sistematik Sampling Secara Acak, yaitu membuat plot sampling secara acak dengan intensitas $0,1 \%$, atau plot berukuran 20 $\mathrm{m} \times 50 \mathrm{~m}$ pada tegakan umur 4 tahun, 5 tahun dan 6 tahun. Volume pohon dihitung menggunakan rumus menurut Chapman dan Meyer (1949) sebagai berikut,

$\mathrm{V}=\left(\mathrm{d}^{2}\right) / 4 \times \mathrm{h} \times \mathrm{f}$

Keterangan:

$\mathrm{V}=$ volume pohon

$\mathrm{d}=$ diameter setinggi dada $(\mathrm{cm})$

$\mathrm{h}=$ tinggipohon $(\mathrm{m})$

$\mathrm{f}=$ angka bentuk $(0,70)$

b. Faktor sifat kayu

Untuk mengetahui sifat kayu dan rendamen pulpnya dilakukan dengan cara mengambil contoh kayu pada plot sampling. Masing-masing kelas umur diambil 3 contoh sebagai ulangan. Rulliaty dan Lempang (2004), masing-masing bagian batang diambil sepanjang $50 \mathrm{~cm}$, sampel kayu dicacah (chiping) untuk uji sifat fisik dan kimia kayu, serta dimensi sertanya.

c. Nilai finansial pembangunan HTI

Analisis dilakukan dengan menghitung biaya pembangunan dan hasil yang diperoleh selama satu daur. Biaya pembangunan HTI terdiri atas biaya persemaian, persiapan lahan, penanaman, pemeliharaan, dan pemanenan. Data ini diperoleh dari dokumen perusahaan, sebagai keleng- 
kapan informasi dilakukan pula wawancara terhadap karyawan perusahaan dengan menggunakan kuisioner.

Analisis kelayakan digunakan untuk menghitung kondisi finansial pengusahaan HTI selama jangka satu daur. Faktor-faktor yang menentukan kelayakan finansial digunakan rumus menurut Gittinger (1982) adalah: Net Present Value (NPV), Benefit Cost Ratio (BCR) dan Internal Rate of Return (IRR).

\section{Aspek sosial}

Aspek sosial yang dikaji adalah jumlah tenaga kerja langsung pada pengelolaan HTI sebelum penurunan daur dan sesudah penurunan daur. Data standar tenaga kerja setiap kegiatan, dihitung dengan satuan jumlah hari orang kerja $(\mathrm{HOK}) /$ hektar$)$, yang dimulai dari kegiatan persemaian, penanaman, pemeliharaan dan pemanenan.

Analisis yang digunakan adalah pendekatan serapan tenaga kerja pada daur awal (sebelum penurunan daur) dan daur operasional (setelah penurunan daur). Waktu analisis disamakan dengan kajian finansial, yaitu angka pertemuan daur 7 tahun dengan daur 5 tahun (berarti dengan masa kontrak HTI 35 tahun), sehingga sebelumnya 5 rotasi menajdi 7 rotasi. Analisis dilakukan pada jumlah tenaga kerja langsung (kontraktor dan tenaga kerja lapangan).

\section{HASIL DAN PEMBAHASAN}

\section{A. Gambaran Umum Lokasi Penelitian}

\section{Areal HTI PT. Arara Abadi}

Kawasan yang di survei berlokasi di Kabu- paten Siak, Riau, memiliki areal konsesi seluas 299.975 ha, tanaman pokok seluas \pm 210.000 ha, berada pada ketinggian 8-100 m dpl, topografi datar-bergelombang, kelerengan $0-15 \%$. Jenis tanah 42,40\% adalah Organosol (gambut) dan 28,09\% adalah Podsolik (mineral), curah hujan rata-rata $2.713 \mathrm{~mm} / \mathrm{th}$, termasuk tipe iklim A. Penyinaran matahari rata-rata 4,1 jam/hari (49 $\%$ ), suhu udara rata-rata $29,4{ }^{\circ} \mathrm{C}$ dan kelembaban udara $84 \%$, kecepatan angin antara 18,5-22,8 $\mathrm{km} / \mathrm{jam}$. Dikaitkan dengan standar kebutuhan tanaman, maka kondisi lingkungan fisik pada areal ini memenuhi syarat bagi pertumbuhan tanaman jenis Acacia dan Ekaliptus.

\section{Areal HTI PT. Wirakarya Sakti (WKS)}

Kawasan yang disurvei berlokasi di Kabupaten Jabon Barat, Jambi. Jenis tanah berupa lahan mineral seluas 53,66 \% dan lahan gambut seluas 46,34\%. Kawasan lahan darat terletak pada ketinggian 6- $469 \mathrm{~m}$ dpl, dengan jenis tanah inceptisol, ultisol, spodsol, topografi datar hingga sangat curam. Lahan rawa (tanah organik) berada pada ketinggian 3-6 m dpl, dengan jenis tanah histosol. Formasi geologi terdiri atas endapan rawa, endapan alluvial, dan granit. Kawasan ini termasuk iklim tipe $\mathrm{A}$, jumlah curah hujan antara $2.034-2.471 \mathrm{~mm} /$ tahun, suhu udara $26,4^{\circ} \mathrm{C}$, kelembaban udara $85 \%$.

\section{Areal HTI PT. Riau Andalan Pulp dan Paper (RAPP)}

Kawasan yang disurvei berlokasi di Kabupaten Pelalawan, Riau. Jenis tanah terdiri atas lahang mineral seluas 151.500 ha dan rawa/ gambut seluas 83.640 ha. Kawasan berada pada ketinggian 20-160 m dpl dan termasuk iklim tipe A.

Tabel(Table) 1. Potensi dan riap volume tegakan A.crassicarpa (Potency and stand volume of A. crassicarpa)

\begin{tabular}{cccccrrr}
\hline $\begin{array}{c}\text { Umur } \\
\text { tanaman } \\
\begin{array}{c}\text { (Plant age }) \\
\text { (tahun/years })\end{array}\end{array}$ & $\begin{array}{c}\text { Tinggi } \\
(\text { Height }) \\
(\mathrm{m})\end{array}$ & $\begin{array}{c}\text { Diameter } \\
(\text { Diameter }) \\
(\mathrm{cm})\end{array}$ & $\begin{array}{c}\text { Volume } \\
(\text { Volume }) \\
\left(\mathrm{m}^{3}\right)\end{array}$ & $\begin{array}{c}\text { Survival } \\
(\%)\end{array}$ & $\begin{array}{c}\text { Volume } \\
(\text { Volume }) \\
\left(\mathrm{m}^{3} / \mathrm{ha}\right)\end{array}$ & $\begin{array}{c}\text { MAI } \\
\mathrm{m}^{3} / \mathrm{ha} / \mathrm{th}\end{array}$ & $\begin{array}{c}\text { CAI } \\
\mathrm{m}^{3} / \mathrm{ha}\end{array}$ \\
\hline 1. & 4,1 & 4,6 & 0,005 & 22,89 & 1,9 & 1,9 & - \\
2. & 9,3 & 8,4 & 0,036 & 38,18 & 22,9 & 11,5 & 21,0 \\
4. & 14,0 & 11,8 & 0,108 & 36,96 & 66,5 & 22,2 & 43,6 \\
5. & 17,9 & 15,0 & 0,222 & 29,79 & 110,2 & 27,6 & 43,7 \\
6. & 20,9 & 18,0 & 0,374 & 21,97 & 136,9 & 27,4 & 26,7 \\
7. & 23,4 & 20,8 & 0,559 & 16,32 & 152,0 & 25,3 & 15,1 \\
\hline
\end{tabular}




\section{B. Aspek Produksi dan Sifat Kayunya}

\section{Faktor pertumbuhan}

Data pertumbuhan dan riap volume pada tegakan A. crassicarpa pada berbagai kelas umur, diperoleh dari rata-rata pengukuran dari ketiga lokasi plot sampling, sebagaimana disajikan dalam Tabel 1.

Dari Tabel 1 terlihat bahwa volume pohon meningkat seiring bertambahnya umur pohon, sebaliknya riap tegakan (MAI dan CAI) menurun mulai umur 5 tahun disebabkan survival menurun seiring dengan bertambahnya umur pohon. Volume pohon meningkat seiring dengan pertambahan umur pohon yang diikuti perkembangan biomassa. Rochmayanto (2009) menyatakan bahwa jumlah biomassa pada tegakan $A$. crassicarpa meningkat seiring dengan bertambahnya umur tegakan, yaitu umur 4 tahun menghasilkan rerata biomassa $56.355,11 \mathrm{~kg} / \mathrm{ha}$, sedangkan tegakan umur 5 tahun menghasilkan rerata biomassa $79.019,85 \mathrm{~kg} / \mathrm{ha}$. Sementara Sudarmalik $d k k$. (2007) melaporkan bahwa bahwa $A$. crassicarpa umur 4 tahun nilai biomassanya sebesar 139,56 kg/ pohon, sedangkan umur 5 tahun biomassanya sebesar 203,62 kg/pohon.

Persentase tumbuh (survival) pada tegakan $A$. crassicarpa menurun disebabkan rentan roboh (tumbang), sebagaimana data yang tercantum dalam Tabel 1, bahwa pada umur 4 tahun survival sebesar 29,79\% dan umur 5 tahun menurun menjadi $21,97 \%$. Perkembangan biomassa yang sangat cepat pada $A$. crassicarpa menyebabkan kurangnya keseimbangan antara bobot biomassa dan kekokohan perakaran. Lahan gambut bersifat porous menyebabkan sistem perakaran tanaman kurang stabil, serta dipicu oleh tiupan angin sehingga tumbang. Berdasarkan laporan PT. Arara Abadi (2008), bahwa tegakan A. crassicarpa umur 3 tahun survival nya 49,82\%, sedangkan pada umur 4 tahun menurun hanya $27,38 \%$. Hal ini didukung pernyataan oleh Anonim (2009), bahwa $A$. crassicarpa kekokohannya hanya ber-

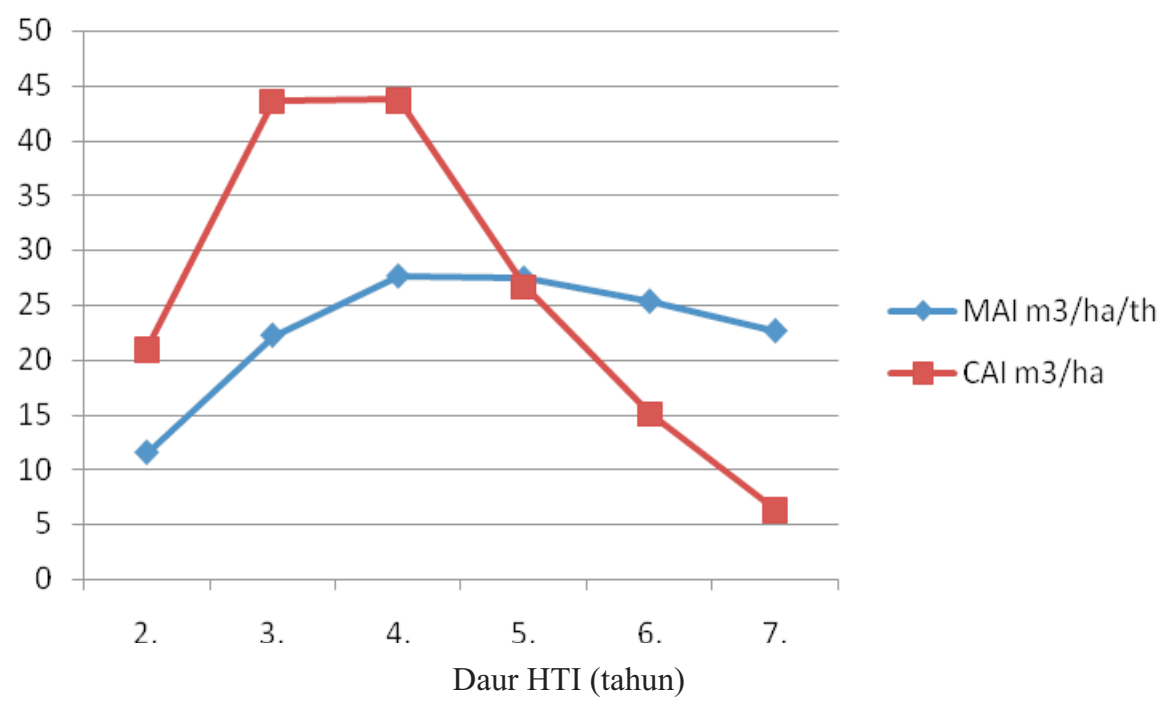

Gambar (Figure) 1. Kurva riap volume MAI dan CAI pada tegakan A. crassicarpa (Volume curve of MAI and CAI at A. crassicarpa)

Tabel (Table) 2. Rendamen kayu A. crassicarpa (Pulp yield of A. crassicarpa)

\begin{tabular}{ccc}
\hline $\begin{array}{c}\text { Umur } \\
\text { (Plant }\end{array}$ & $\begin{array}{c}\text { Rendamen Pulp* } \\
\text { age })\end{array}$ & $\begin{array}{c}\text { Rendamen Pulp ** } \\
\text { (Pulp yield })(\%)\end{array}$ \\
\hline 4 & 54,20 & 56,22 \\
5 & 50,46 & 53,68 \\
6 & 47,15 & 52,12 \\
7 & - & 52,04 \\
\hline
\end{tabular}

* Hasil uji di Puslit Hasil Hutan Bogor (2010)

**Sumber (Source) PT. Arara Abadi (2008) 
Tabel (Table) 3. Berat jenis $\left(\mathrm{kg} / \mathrm{m}^{3}\right)$ dan kadar air (\%) kayu A. crassicarpa (Density and moisture content of A. crassicarpa)

\begin{tabular}{cccccc}
\hline $\begin{array}{l}\text { Umur } \\
\text { (Age) }\end{array}$ & $\begin{array}{c}\text { Berat jenis } \\
\text { (Dahun } \\
\text { (years) }\end{array}$ & $\begin{array}{c}\text { Berat Jenis** } \\
\text { (Density) }\end{array}$ & $\begin{array}{c}\text { Kualitas } \\
\text { (Quality) }\end{array}$ & $\begin{array}{c}\text { Kadar Air } \\
\text { (Moisture content) }\end{array}$ & $\begin{array}{c}\text { Kadar air basah } \\
\text { (wet moisture } \\
\text { content) }\end{array}$ \\
\hline 4 & 480,0 & 383,89 & I & 53,56 & 15,45 \\
5 & 490,0 & 465,30 & I & 53,73 & 15,48 \\
6 & 660,0 & 488,12 & II & 39,20 & 14,75 \\
7 & - & 485,81 & II & - & - \\
\hline
\end{tabular}

*Hasil uji di Puslitbang Hasil Hutan Bogor (2009)

**Sumber (Source) PT. Arara Abadi Riau (2008)

Tabel (Table) 4. Kadar lignin, selulose dan kualitas pulp kayu A.crassicarpa (Lignin, cellulose and pulp quality of A. crassicarpa wood)

\begin{tabular}{|c|c|c|c|c|c|c|}
\hline \multirow{2}{*}{$\begin{array}{l}\text { Umur } \\
(A g e) \\
\text { Tahun } \\
\text { (Year) }\end{array}$} & \multicolumn{2}{|c|}{$\begin{array}{c}\text { Lignin } \\
\text { (Lignin) }(\%)\end{array}$} & \multirow{2}{*}{$\begin{array}{c}\text { Kualitas } \\
\text { Pulp } \\
\text { (Pulp } \\
\text { Quality) }\end{array}$} & \multicolumn{2}{|c|}{$\begin{array}{c}\text { Selulose } \\
(\text { Cellulose })(\%)\end{array}$} & \multirow{2}{*}{$\begin{array}{l}\text { Kualitas Pulp } \\
\text { (Pulp Quality) }\end{array}$} \\
\hline & $\begin{array}{c}\text { Contoh } \\
\text { (sample) I }\end{array}$ & $\begin{array}{c}\text { Contoh } \\
\text { (sample) II }\end{array}$ & & $\begin{array}{c}\text { Contoh } \\
\text { (sample) I }\end{array}$ & $\begin{array}{c}\text { Contoh } \\
\text { (sample) II }\end{array}$ & \\
\hline 4 & 27,23 & 27,75 & II & 45,91 & 46,03 & I \\
\hline 5 & 27,25 & 27,89 & II & 51,57 & 52,59 & I \\
\hline 6 & 27,53 & 28,11 & II & 52,45 & 52,48 & I \\
\hline
\end{tabular}

tahan maksimal sampai umur 3 tahun, terutama dari materi bibit cutting.

Riap volume tegakan selama satu daur dapat dibedakan antara riap rata-rata tahunan (Mean Annual Increament, MAI) dan riap rata-rata periode berjalan (Current Annual Increament, CAI). Pada kajian ini terlihat bahwa MAI dan CAI maksimum tercapai pada umur 4 tahun dengan hasil masing-masing $27,6 \mathrm{~m}^{3} / \mathrm{ha} / \mathrm{thn}$ dan $43,7 \mathrm{~m}^{3} /$ ha/thn.

Dalam Gambar 1, terlihat kurva MAI dan CAI berpotongan pada umur 4-5 tahun, sehingga daur teknis tercapai pada umur umur tersebut. Menurut Simon (1996) bahwa titik perpotongan antara kurva MAI dan CAI merupakan umur dimana tegakan mencapai volume maksimal, sehingga ditetapkan sebagai daur teknis. Apabila suatu tegakan tidak beriap, maka dikatakan tegakan tersebut mencapai klimaks dan mulai saat itu dan seterusya riap tegakan sama dengan nol.

Karena pertumbuhan menurun setelah titik perpotongan, maka daur teknis untuk HTI $A$. crassicarpa di lahan gambut tercapai antara umur $4-5$ tahun. Seiring dengan ditemukannya klonklon unggul disertai penerapan silvikultur intensif (silin), maka $A$. crassicarpa dapat dipanen antara umur 4-5 tahun untuk tujuan bahan baku dan kertas. Berdasarkan hal ini, daur tebang yang diizinkan oleh pihak perusahaan adalah antara umur 4-5 tahun.

\section{Faktor sifat kayu}

a. Rendamen pulp

Umur tanaman sangat berpengaruh terhadap rendamen dan produksi, sebagaimana hasilnya disajikan dalam Tabel 2.

Kayu $A$. crassicarpa umur muda (4 tahun) menghasilkan persentase rendamen lebih tinggi dibanding umur yang lebih tua (umur 5-7 tahun). Porsi juvenil lebih besar pada kayu umur muda, sehingga berpotensi menghasilkan rendamen (bubur kayu) yang lebih banyak, hanya membutuhkan komsumsi kayu dan zat kimia lebih banyak. Kayu umur lebih muda membutuhkan komsumsi kayu lebih banyak dibanding umur kayu yang lebih tua (PT. Arara Abadi, 2008).

b. Kualitas pulp berdasarkan berat jenis

Berat Jenis (BJ) hasil uji dari Puslitbang Hasil Hutan nilainya relatif sama dengan hasil uji oleh PT. Arara Abadi (Tabel 3).

BJ kayu meningkat seiring dengan pertambahan umur, sebaliknya KA menurun. BJ kayu umur 4-5 tahun tergolong rendah sehingga termasuk kelas kualitas I (baik), sedangkan kayu umur 6 tahun tergolong sedang sehingga termasuk kelas kualitas II. Menurut ginoga dalam Malik et al. (2006) bahwa berat jenis kayu mang- 
Tabel(Table)5. Dimensi dan turunan serat pada kayu A. crassicarpa (A. crassicarpa wood fiber dimension and its derivate)

\begin{tabular}{lcccccc}
\hline \multirow{2}{*}{$\begin{array}{c}\text { Dimensi Serat } \\
\text { (Fiber Dimension })\end{array}$} & \multicolumn{5}{c}{ Umur Contoh Kayu (Sample of wood age) } \\
\cline { 2 - 7 } & $\begin{array}{c}\text { Nilai } \\
\text { (Value) }\end{array}$ & $\begin{array}{c}\text { Kualitas } \\
\text { (Quality) }\end{array}$ & $\begin{array}{c}\text { Nilai } \\
(\text { Value })\end{array}$ & $\begin{array}{c}\text { Kualitas } \\
\text { (Quality) }\end{array}$ & $\begin{array}{c}\text { Nilai } \\
\text { (Value) }\end{array}$ & $\begin{array}{c}\text { Kualitas } \\
\text { (Quality) }\end{array}$ \\
\hline Panjang Serat & $1.343,74$ & II & $1.306,58$ & II & $1.289,85$ & II \\
(fiber length) $(\mu)$ & & & & & & \\
Diameter Serat & 35,68 & I & 34,24 & I & 52,24 & I \\
(fiber diameter) $(\mu)$ & 0,14 & I & 0,14 & I & 0,22 & 1 \\
Runkle Ratio & 38,01 & III & 38,09 & III & 50,47 & II \\
Felting Power & 22,00 & I & 20,20 & I & 22,90 & 1 \\
Muhlsteph Ratio & 0,88 & I & 0,88 & I & 0,86 & 1 \\
Flexibility Ratio & 0,06 & I & 0,06 & I & 0,09 & 1 \\
Coef.of Rigidity & & & & & & \\
\hline
\end{tabular}

ium pada setiap umur tidak memperlihatkan perbedaan yang nyata. Sedangkan menurut Kartiwa (2006) bahwa massa jenis kayu mempengaruhi rendemen pulp dengan koefisien regresinya $\left(\mathrm{R}^{2}\right)$ $=0,481$. Artinya rendemen pulp hanya $48,1 \%$ dipengaruhi oleh massa jenis kayu masih ada faktor lain yang mempengaruhinya.
Menurut Siagian et al. (1995) bahwa BJ tinggi menyulitkan penetrasi bahan pemasak ke dalam kayu untuk pengolahan proses kimia, mengakibatkan kualitas untuk kertas lebih rendah. Pengujian contoh kayu yang dilakukan oleh Puslitbang Hasil Hutan nilai Bjnya lebih tinggi dibanding data BJ yang diperoleh dari PT. Arara Abadi.

Tabel(Table) 6. Dinamika finansial pada HTI lahan mineral dan lahan gambut (Financial preview of Acacia plantation on mineral and peat land)

\begin{tabular}{|c|c|c|c|c|c|c|c|c|}
\hline \multirow{3}{*}{$\begin{array}{l}\text { Tipe } \\
\text { Lahan } \\
\text { (Land } \\
\text { Type) }\end{array}$} & \multicolumn{8}{|c|}{ Umur Tegakan (Stand Age) } \\
\hline & \multicolumn{2}{|c|}{4 tahun (years) } & \multicolumn{2}{|c|}{5 tahun (years) } & \multicolumn{2}{|c|}{6 tahun (years) } & \multicolumn{2}{|c|}{7 tahun (years) } \\
\hline & NPV/ha & BCR & NPV/ha & BCR & NPV/ha & BCR & NPV/ha & BCR \\
\hline $\begin{array}{c}\text { Lahan } \\
\text { mineral } \\
\text { (Dry Land) }\end{array}$ & $\begin{array}{c}3.128 .659,3 \\
5\end{array}$ & 1,07 & $\begin{array}{c}4.824 .561,8 \\
3\end{array}$ & 1,11 & $5.923 .090,27$ & 1,15 & $3.548 .526,14$ & 1,11 \\
\hline $\begin{array}{c}\text { Gambut } \\
\text { (Peat } \\
\text { Land })\end{array}$ & $\begin{array}{c}4.670 .791,6 \\
1\end{array}$ & 1,10 & $\begin{array}{c}2.804 .815,4 \\
2\end{array}$ & 1.07 & $750.971,10$ & 1,02 & - & - \\
\hline
\end{tabular}

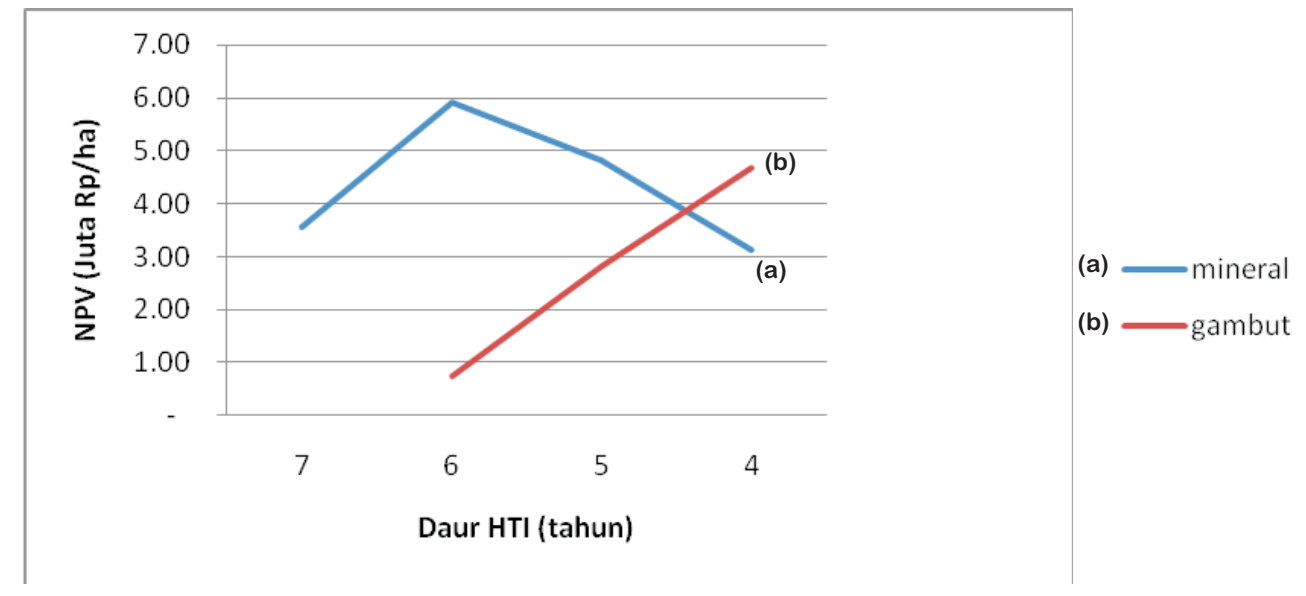

Gambar(Figure) 2. Dinamika finansial akibat penurunan daur tebang pada HTI (Financial preview of Acacia plantation on mineral and peat land) 
BJ kayu dapat dipengaruhi oleh kondisi tempat tumbuh, iklim, geografis dan spesies (Haygreen dan Bowyer, 1996). Berdasarkan nilai BJ, kayu A. crassicarpa umur 4-5 tahun kualitasnya lebih baik dibanding kayu umur 6 tahun.

BJ merupakan salah satu sifat fisik kayu yang dipersyaratkan untuk tujuan bahan baku dan kertas. Kayu yang memiliki BJ >700 membutuhkan kondisi pemasakan yang lebih lama dibandingkan BJ 490 - 700 (Pasaribu dan Tampubolon, 2007). Sedangkan kadar air kayu tidak berpengaruh terhadap kualitas, hanya mempengaruhi bobot kayu.

c. Kualitas pulp berdasarkan kadar lignin dan selulosa

Komponen kimia yang berpengaruh dalam pembuatan pulp yaitu kadar selulosa, lignin dan zat ekstraktif. Yang sangat bervariasi antara satu jenis kayu dengan kayu yang lain. Variasi tersebut dapat dilihat pada satu pohon di lokasi yang berbeda. Selulosa sebagian besar terdapat di dalam lapisan sekunder dinding serat (S2) sedangkan lignin banyak terdapat di lamela tengah. Zat ekstraktif umumnya lebih banyak terdapat di bagian kayu teras yaitu di dalam rongga sel atau rongga rongga kecil dalam dinding sel (Sudrajat, 1979, dalam Fatimah, 2003). Komponen kimia kayu terdiri atas fraksi karbohidrat diantaranya kadar selulosa, dan bagian bukan karbohidrat adalah kadar lignin.

Kadar lignin dan selulosa meningkat seiring dengan pertambahan umur kayu, walaupun berada pada standar kelas kualitas yang sama yaitu kualitas II (sedang) untuk lignin, serta kualitas I (baik) untuk selulosa pada kelas umur 4 hingga 6 tahun. Kualitas yang baik dapat menghasilkan rendamen yang tinggi serta jenis kertas dan rayon yang baik. Berdasarkan hasil pengujian dapat disimpulkan bahwa kayu $A$. crassicarpa dari mulai umur 4 tahun, memenuhi syarat untuk menghasilkan dan kertas yang berkualitas baik, karena mengandung kadar lignin yang rendah dan kadar selulosa yang tinggi. Walaupun kedua faktor ini kadarnya relatif sama pada tegakan umur 4-6 tahun.

Lignin termasuk komponen kimia yang berperan sebagai zat penguat untuk mendukung tegaknya pohon, sedangkan peranan lignin dalam kayu sebagai pengikat antara serat, sehingga terbentuk jaringan kayu yang kuat. Kadar lignin yang tinggi menyebabkan kayu semakin kuat dan

Tabel(Table) 7. Dinamika serapan tenaga kerja akibat penurunan daur HTI A. crassicarpa (Dynamics of labour needed as effect of decreased rotation of A. crassicarpa plantation)

\begin{tabular}{lcccc}
\hline \multirow{2}{*}{$\begin{array}{c}\text { Jenis lahan } \\
\text { (land type) }\end{array}$} & $\begin{array}{c}\text { Daur 4 tahun } \\
\text { (4 years rotation) }\end{array}$ & $\begin{array}{c}\text { Daur } 5 \text { tahun } \\
\text { (5 years rotation) }\end{array}$ & $\begin{array}{c}\text { Daur 6 tahun } \\
\text { (6 years rotation) })\end{array}$ & $\begin{array}{c}\text { Daur } 7 \text { tahun } \\
\text { (7 years rotation) }\end{array}$ \\
\hline $\begin{array}{l}\text { Lahan mineral } \\
\text { (Dry land) }\end{array}$ & $1.766 .876,94$ & $1.413 .501,55$ & $1.009 .643,96$ & $1.177 .917,96$ \\
$\begin{array}{l}\text { Gambut } \\
\text { (Peat land) }\end{array}$ & $1.492 .169,51$ & $1.193 .735,61$ & $852.668,29$ & $994.779,67$ \\
\hline
\end{tabular}

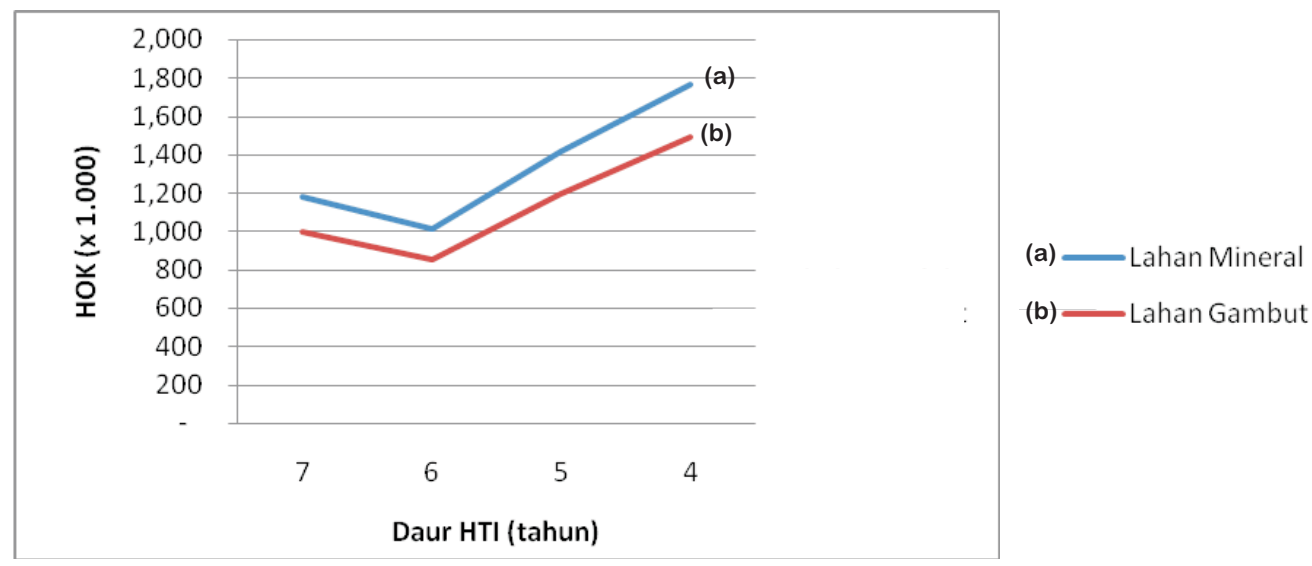

Gambar(Figure) 3. Dinamika serapan tenaga kerja akibat penurunan daur tanaman A. crassicarpa (Dynamics of labour needed as effect of rotation decreased of A. crassicarpa plantation) 
tidak mudah retak, sehingga berdampak positif terhadap kayu untuk papan serat. Namun kadar lignin yang tinggi berdampak negatif terhadap pengolahan kayu, karena dapat menyebabkan kualitas kertas lebih rendah. Kayu yang memiliki BJ dan kadar lignin yang tinggi serta selulosa yang rendah, akan menghasilkan kualitas yang rendah dan waktu pengolahan menjadi lebih lama (Siagian, et al., 1995).

d. Kualitas pulp berdasarkan dimensi serat

Dimensi serat dapat digunakan untuk menentukan nilai turunan serat yang parameternya adalah Runkle Ratio, Felting Power, Muhlsteph Ratio, Flexibility Ratio dan Coef.of Rigidity (Tabel 5). Dimensi serat seperti panjang serat, diameter lumen, tebal dinding sel dan diameter lumen memiliki hubungan yang komplek satu sama lain dan mempunyai pengaruh yang mendasar terhadap sifat fisik pulp dan kertas serta tujuan penggunaannya (Anonim dalam Prabawa B.S, 2005). Pengaruh dimensi serat terhadap kekuatan kertas secara individu (bukan gabungan) lebih kecil dibandingkan dengan pengaruh turunannya.

Kayu A. crassicarpa umur 4, 5 dan 6 tahun memiliki panjang serat yang relatif sama dan termasuk kualitas II (sedang), sedangkan diameter serat termasuk kualitas I (baik). Semakin panjang serat kayu kekuatan sobek makin tinggi, sedangkan diameter serat yang lebar menghasilkan kertas yang kompak. Nilai turunan serat dari ketiga kelas umur yang diuji memiliki standar kualitas yang relatif sama, kecuali Felting Power kayu umur 6 tahun termasuk kualitas II. Berdasarkan dimensi serat, kayu A. crassicarpa umur 4-6 tahun tergolong kelas kualitas I - II. Walaupun umur relatif masih muda yaitu antara umur 4-5 tahun, tetapi sifat kayu memenuhi standar kualitas sesuai yang dipersyaratkan oleh industri dan kertas.

\section{Nilai finansial pembangunan HTI}

Aspek finansial merupakan indikator investasi yang berbeda antara pengeloaan HTI di lahan mineral (lahan kering) dengan di lahan gambut. Pengelolaan HTI pada lahan gambut, menunjukkan nilai NPV dan BCR yang semakin besar akibat daur tebang semakin pendek. Berdasarkan hasil analisis diperoleh hasil maksimum pada umur 4 tahun, sehingga daur ekonomis dicapai umur 4 tahun. Hal ini terjadi karena semakin tua umur pohon A. crassicarpa, persentase hidupnya (survival) semakin rendah, akibat banyaknya pohon yang roboh seiring dengan bertambahnya umur tegakan.
Hasil kajian tersebut sejalan dengan hasil kajian Sudarmalik (2008) yang dilakukan pada tegakan $A$. crassicarpa kelas umur 4 dan 5 tahun bahwa tingkat keuntungan terbesar pada daur tebang umur 4 tahun, baik pada rotasi 1 maupun rotasi 2. Sedangkan pada daur tebang 5 tahun tingkat keuntungan menurun dikarenakan potensi tegakan semakin berkurang. Berdasarkan hal ini, maka kelayakan finansial atau daur ekonomis untuk HTI A. crassicarpa di lahan gambut adalah pada daur umur 4 tahun.

Penentuan daur optiman menurut indikator finansial merupakan salah satu upaya untuk memperoleh keuntungan maksimal. Namun demikian, faktor lain harus tetap diperhatikan untuk menjamin kontinyuitas usaha antara lain tingkat produksi, kebijakan rente ekonomi dan retribusi kayu (Handadhari et al., 2005).

\section{Aspek Sosial}

Pembangunan HTI dapat menyerap tenaga kerja, sehingga kajian sosial difokuskan pada aspek serapan tenaga kerja dan berimplikasi terhadap peningkatan kesejahteraan masyarakat di sekitar hutan. Penurunan daur selain meningkatkan produktivitas lahan hutan dan hasil kayu, dari segi dimensi sosial dapat meningkatkan kesejahteraan masyarakat di sekitar hutan. Memperpendek daur HTI, maka frekuensi serapan tenaga kerja semakin meningkat.

Hasil kajian menunjukkan bahwa daur umur 4 tahun menyerap tenaga kerja paling tinggi pada unit manajemen seluas 51.215 ha, sedangkan daur umur 6 tahun menunjukkan kapasitas serapan tenaga kerja paling rendah.

Berdasarkan kajian ini, diketahui bahwa daur umur 4 tahun merupakan serapan tenaga kerja paling maksimal, kondisi ini berlaku pada pengelolaan HTI lahan mineral dan lahan gambut. Perubahan volume tebang tidak selalu lebih kecil dalam daur yang pendek pada luas unit manajemen yang sama, semakin singkat daur tebang semakin luas tebangan tahunan.

Pengelolaan HTI diharapkan memperoleh hasil sesuai kriteria yang dipersyaratkan oleh industri dan kertas, yaitu produksi dan rendamen tinggi, daur pendek, dan menghasilkan dan kertas yang berkualitas baik. Pengelolaan HTI tetap berazaskan pengelolaan hutan lestari (sustainable forest management), yaitu memperoleh kuantitas dan kualitas kayu yang maksimal dan lestari, serta ramah lingkungan. 


\section{KESIMPULAN}

\section{A. Kesimpulan}

1. Aspek produksi yang berkaitan dengan pertumbuhan menunjukkan bahwa daur teknis dan ekonomis pada HTI $A$. crassicarpa tercapai antara umur 4 - 5 tahun. Sedangkan sifat kimia dan serat kayu $A$. crassicarpa tergolong kualitas I dan II dari umur 4 - 6 tahun, dan rendamen paling tinggi diproleh dari kayu umur 4 tahun.

2. Aspek sosial khususnya penyerapan tenaga kerja menunjukkan nilai terbesar pada daur umur 4 tahun.

3. Penurunan daur HTI A. crassicarpa dapat dilakukan, karena daur teknis dan daur ekonomis tercapai pada umur 4-5 tahun, serta sifat kayunya termasuk kualitas baik untuk bahan baku pulp. Ditinjau dari azas pengelolaan hutan tidak berdampak negatif terhadap kelestarian hutan, dan layak untuk diopresionalkan pada pengelolaan HTI pulp.

\section{B. Saran}

Kajian penurunan daur HTI- ini perlu perluasan wilayah survey secara regional, sehingga hasil kajian lebih akurat dan menghasilkan rekomendasi yang sifatnya nasional, sebagai dasar pengambilan kebijakan pengelolaan HTI pulp.

\section{DAFTAR PUSTAKA}

Anonim, 2009. Spesies Identity Acacia crassicarpa (Kutipan internet Desember 2009) $w w w$. worldagroforestrycentre.org/SEA/. Prosea.

Chapman. H.H and W.H. Meyer. 1949. Forest Mensuration. McGraw-Hill Book Company, Inc. New york.

Fatimah, S. 2003. Korelasi kanonik antara sifat dasar kayu dengan sifat pulp sulfat. Skripsi Jurusan Manejemen Hutan Fahutan. Institut Pertanian Bogor. Bogor. (Tidak dipublikasikan).

Gittinger J.P. 1982. Economic Analysis of Agricultur Projects. The Johns Hopkins University Press. Baltimore, Maryland.

Handadhari T, A. Sumitro, SP. Warsit, S. Widodo. 2005. Analisis Pungutan Rente Ekonomi Kayu Bulat Hutan Tanaman Industri di Indonesia. Jurnal Penelitian Sosial dan Ekonomi Kehutanan. No. 2(2) : 137 - 148.
Haygreen J.G. dan Jim L. Bowyer. 1996. Hasil Hutan dan Ilmu Kayu diterjemahkan oleh Dr. Ir. Sutjipto A.H. Gajah Mada University Press. Yogyakarta.

Indriyanto. 2006. Ekologi Hutan. PT. Bumi Aksara. Jakarta.

Istomo. 2008. Pemanfaatan Lahan Gambut untuk Pengembangan Hutan anaman Kayu; Riset yang perlu dipersiapkan. Bahan kuliah disampaikan pada Kuliah Umum BPHPS-Kuok, Riau.

Kartiwa, W. 2006. Variabilitas massa jenis kayu daun lebar tropis terhadap karakter serat, kimia dan pulp sulfat. Jurnal Ilmu dan Teknologi Kayu Tropis Vol. 4. No. 2. Juli 2006. Masyarakat Peneliti Kayu Indonesia.

Malik, J., Adi, S. dan Osly, R. 2006. Sari hasil penelitian mangium (A.mangium Wild). http://www. penelitian mangium.htm. Diakses tanggal 10 Agustus 2009.

Pasaribu R. A. dan Tampubolon 1997. Persyaratan Teknis Bahan Baku, Air, dan Bahan Penolong untuk Industri, Kertas dan Rayon. Diktat Pelatihan Verivfikasi Eksportir Terdaftar Produk Industri Kehutanan (ETPIK). Puslitbang Teknologi Hasil Hutan. Bogor.

Prabawa. B.S. 2005. Sifat Fisik dan Dimensi Serat Kayu Mangium Empat Tahun dari Daerah Sebulu, Kalimantan Timur. Jurnal Penelitian Hasil Hu$\tan$ 23(5): 339-348. Pusat Penelitian dan Pengembangan Teknologi Hasil Hutan. Bogor.

Rochmayanto. 2008. Perubahan kandungan karbon dan nilai ekonominya pada konservasi hutan rawa gambut menjadi hutan tanaman industri pulp. Tesis. Fakultas Kehutanan Institut Pertanian Bogor. Bogor. (Tidak diterbitkan)

Rulliaty, S. dan M. Lempang. 2004. Sifat Anatomi dan Fisis Kayu Jati dari Muna dan Kendari Selatan. Jurnal Penelitian Hasil Hutan. Vol. 22 No.4. Pusat Litbang Teknologi Hasil Hutan. Bogor.

Siagian, R.M. K. Purba dan R.A. Pasaribu. 1995. Peranan berat jenis kayu terhadap sifat pulp. Pusat Litbang HH dan Sosek Hutan. Bogor.

Simon, H. 1996. Metode Inventore Hutan. Penerbit Aditya Media. Yogyakarta.

Sudarmalik, Kamindar, R. dan Yuslinda, A. 2007. Kajian Karakteristik HTI Pulp rotasi-1 dan rotasi-2. LHP, BPHPS. Riau.

PT. Arara Abadi. 2008. Rencana Kerja Periode Tahun 2008-2017. Riau.

Wibowo, A. 2009. Pengelolaan Lingkungan Hutan Tanaman. Workshop Sintesa UKP, Puslit Hutan Tanaman. Jakarta. 